\title{
Clostridium pascui sp. nov., a New Glutamate-Fermenting Sporeformer from a Pasture in Pakistan
}

\author{
E. WILDE, ${ }^{* 1}$ M. D. COLLINS, ${ }^{2}$ AND H. HIPPE ${ }^{3}$ \\ Institut für Mikrobiologie der Universität, D-37077 Göttingen, ${ }^{1}$ and Deutsche Sammlung von \\ Mikroorganismen und Zellkulturen GmbH, D-38124 Braunschweig, ${ }^{3}$ Germany, and Institute \\ of Food Research, Reading Laboratory, Reading RG6 6BZ, United Kingdom ${ }^{2}$
}

\begin{abstract}
Four strains of an obligately anaerobic spore-forming bacterium were isolated from soil samples from a donkey pasture in Pakistan. Comparative 16S rRNA sequence analysis demonstrated that the strains are members of phylogenetic cluster I of the genus Clostridium (Collins et al. 1994). The strains are mesophilic, nonsaccharolytic, and nonproteolytic, utilize glutamate and histidine, and produce indole. Acetate, butyrate, ethanol, hydrogen, and carbon dioxide are the products of fermentation. Although the strains phenotypically resemble the classical glutamate-fermenting clostridia, such as Clostridium cochlearium, Clostridium tetanomorphum, Clostridium tetani, and especially Clostridium malenominatum, they differ from these organisms in sugar utilization, cellular fatty acid composition, and cellular protein pattern and by a 16S rRNA sequence divergence value of approximately 4 to $8 \%$. Phylogenetically, the strains are more closely related to Clostridium estertheticum (sequence divergence, approximately 5\%) and Clostridium subterminale (sequence divergence, approximately $5 \%$ ) but are phenotypically readily distinguished from these species. On the basis of phenotypic and genotypic criteria, we conclude that the four strains are members of a new species of the genus Clostridium, for which the name Clostridium pascui is proposed. The type strain is strain Cm19 (= DSM 10365).
\end{abstract}

In the course of previous studies aimed at isolation and characterization of glutamate-fermenting bacteria, which led to the revival of the species Clostridium tetanomorphum (26), we recovered four clostridial strains which could not be unambiguously identified as strains of any of the classical glutamate-fermenting species, such as Clostridium cochlearium, Clostridium tetanomorphum, Clostridium tetani, Clostridium malenominatum, and Clostridium limosum. When the identification key of Cato et al. (3) was used, the strains closely resembled $C$. malenominatum. However, differences in electrophoretic cellular protein patterns did not support this classification.

In an attempt to clarify the taxonomic position of these unknown isolates and to determine their relationships with other glutamate-fermenting species, we conducted further phenotypic and genotypic investigations. On the basis of the findings of these studies, we concluded that the four glutamatefermenting soil isolates represent a new species of the genus Clostridium, for which the name Clostridium pascui is proposed.

\section{MATERIALS AND METHODS}

Bacteria. Strains $\mathrm{Cm} 17, \mathrm{Cm} 19^{\mathrm{T}}$ ( $\mathrm{T}=$ type strain), $\mathrm{Cm} 20$, and $\mathrm{Cm} 21$ were isolated from soil samples taken from a donkey pasture in Pakistan. The isolation procedure described by Hippe et al. (13) was used with glutamate as the substrate. The isolates were tested for toxigenicity, and none was positive. Strains of C. malenominatum (DSM $1127^{\mathrm{T}}$ ), C. cochlearium (DSM 666, DSM 667, DSM 2153, DSM 3588, and DSM 1285 ${ }^{\mathrm{T}}$ ), C. tetanomorphum (DSM 528, DSM 665, and DSM $4474^{\mathrm{T}}$ ), C. limosum (DSM $1400^{\mathrm{T}}$ ), Clostridium symbiosum (DSM 934 ${ }^{\mathrm{T}}$ ), Clostridium subterminale (DSM 758, DSM 2636, and DSM 6970 ${ }^{\mathrm{T}}$ ), Clostridium sporosphaeroides (DSM 1294 ${ }^{\mathrm{T}}$ ), Clostridium putrificum (DSM 1734 ${ }^{\mathrm{T}}$ ), Clostridium histolyticum (DSM 2158 ${ }^{\mathrm{T}}$ ), and Clostridium estertheticum (DSM $8809^{\mathrm{T}}$ ) were obtained from the Deutsche Sammlung von Mikroorganismen und Zellkulturen $\mathrm{GmbH}$, Braunschweig, Germany; C. tetanomorphum NCTC 500 was obtained from the National Collection of Type Cultures London, United Kingdom. $C$. tetanomorphum MG1 was isolated and characterized by M. Gottwald (12). The origins of strains of $C$. tetanomorphum and C. tetani without public collection

* Corresponding author. Mailing address: Institut für Mikrobiologie der Universität, Grisebachstr. 8, D-37077 Göttingen, Germany. Phone: 49-(0)551-393796. Fax: 49-(0)551-393793. numbers have been described by Wilde et al. (26). Stock cultures were maintained in Reinforced Clostridial Medium (RCM) (Unipath, Ltd., Basingstoke, United Kingdom) by using the anaerobe culture technique of Hungate (15).

Physiological and biochemical tests. Production of indole, lecithinase, and lipase and hydrolysis of gelatin were studied by using the methods of Holdeman et al. (14). Degradation of ethanolamine and choline was determined as described by Möller et al. (23).

To study the fermentation of glutamate, glutamine, and histidine, Hungate tubes with $10 \mathrm{ml}$ of modified Barker medium containing $0.03 \% \mathrm{~K}_{2} \mathrm{HPO}_{4}$, $0.01 \% \mathrm{MgSO}_{4} \cdot 7 \mathrm{H}_{2} \mathrm{O}, 0.5 \%$ yeast extract, $0.05 \%$ L-cysteine hydrochloride, and $0.0001 \%$ resazurin in tap water were used. Glutamate, glutamine, or histidine was added to a final concentration of $1 \%(\mathrm{wt} / \mathrm{vol})$. Hungate tubes with no amino acids added served as controls. Each tube was inoculated with $0.25 \mathrm{ml}$ of a culture grown for $20 \mathrm{~h}$ in RCM. Growth was recorded by measuring the optical density at $600 \mathrm{~nm}$ after $24 \mathrm{~h}$ of incubation at $37^{\circ} \mathrm{C}$.

Sugar fermentation tests were performed in peptone-yeast extract (PY) medium (14) and were performed as described by Wilde et al. (26), except that 9 instead of 17 different sugars were tested.

The $\mathrm{pH}$ and temperature optima and ranges for growth were determined in PY medium supplemented with $20 \mathrm{mM}$ glutamate. Different $\mathrm{pH}$ values were obtained by buffering the medium with $0.03 \mathrm{M}$ potassium phosphate buffers or Tris-HCl buffers in the range from $\mathrm{pH} 4.5$ to 9.0 . A model TN3 temperature gradient incubator (Toyo Kagaku Sangyo Ltd., Tokyo, Japan) was used to incubate cultures at temperatures ranging from 10 to $51.5^{\circ} \mathrm{C}$.

Additional biochemical properties were studied by using API ATB-32A test strips (BioMerieux, Marcy-l'Etoile, France) which included the following 29 enzymatic tests: acid production from 11 sugars, activity of arylamidase toward 12 amino acids, urea hydrolysis, indole production, nitrate utilization, alkaline phosphatase, arginine dihydrolase activity, and glutamic acid decarboxylase activity. The test strips were inoculated with bacterial suspensions made from 2-day-old cultures on Columbia sheep blood agar plates and adjusted to an optical density of 4 (McFarland scale). The strips were incubated for $4 \mathrm{~h}$ at $37^{\circ} \mathrm{C}$ and then read.

Analysis of fermentation products. Acetate, butyrate, $n$-butanol, and ethanol contents were determined by gas chromatography as described by Gottwald et al. (12).

Antibiotic susceptibility test. Resistance to antibiotics was determined by the agar diffusion test. In an anaerobic glove box, $0.2 \mathrm{ml}$ of a culture grown for $20 \mathrm{~h}$ was inoculated onto an RCM agar plate, and three different antibiotic discs (Unipath, Ltd.) were applied to each plate. The plates were incubated in an anaerobic jar for $24 \mathrm{~h}$. The antibiotics tested were tetracycline $(30 \mu \mathrm{g} / \mathrm{disc})$, chloramphenicol $(30 \mu \mathrm{g} / \mathrm{disc})$, rifampin $(30 \mu \mathrm{g} / \mathrm{disc})$, neomycin $(30 \mu \mathrm{g} / \mathrm{disc})$, ampicillin (10 and $25 \mu \mathrm{g} / \mathrm{disc})$, erythromycin $(10 \mu \mathrm{g} / \mathrm{disc})$, clindamycin $(10 \mu \mathrm{g} /$ disc), and penicillin ( 2 and $5 \mathrm{U} / \mathrm{disc}$ ).

Determination of DNA base composition and DNA-DNA homology. Cultivation and harvesting of the cells were performed as described previously (26). DNA was isolated and purified by using the method of Marmur (20). The G+ $\mathrm{C}$ content was determined by the thermal denaturation method in standard 
saline citrate by using Escherichia coli $\mathrm{K}-12$ strain DSM 498 (G + C content, 51.7 mol\%) as the reference $(19,21)$

DNA-DNA homology values were determined by measuring the renaturation rates of the denatured DNAs as recommended by DeLey et al. (7) and Huss et al. (16).

Gel electrophoresis of soluble cell proteins. Sodium dodecyl sulfate (SDS) polyacrylamide gel electrophoresis was performed by the method of Laemmli (18) by using a Mini Protean II vertical tank apparatus (Bio-Rad Laboratories $\mathrm{GmbH}$, Munich, Germany). The strains were cultivated in PY medium, and the cells were harvested at the end of the exponential growth phase. Cell pellets from $2-\mathrm{ml}$ cultures were suspended in $50 \mu \mathrm{l}$ of SDS sample buffer $(1.51 \mathrm{~g}$ of Tris-HCl [pH 6.8], $4 \mathrm{~g}$ of SDS, $10 \mathrm{ml}$ of 2-mercaptoethanol, $20 \mathrm{mg}$ of bromophenol blue, $100 \mathrm{ml}$ of $\mathrm{H}_{2} \mathrm{O}$ ) and denatured by boiling in a water bath for $5 \mathrm{~min}$. Portions $(8$ of $15 \mu \mathrm{l}$ ) of the samples were subjected to electrophoresis in $12.8 \%$ polyacrylamide. The molecular weight standards used (Pharmacia Biotech Europe $\mathrm{GmbH}$, Freiburg, Germany) included phosphorylase $b$ (molecular weight, 94,000), bovine serum albumin $(67,000)$, ovalbumin $(43,000)$, carbonic anhydrase $(30,000)$, trypsin inhibitor $(20,100)$, and $\alpha$-lactalbumin $(14,400)$. Electrophoresis was car ried out at room temperature and at a constant voltage of $150 \mathrm{~V}$ for $1 \mathrm{~h}$. The gels were stained with Coomassie blue (Serva, Heidelberg, Germany), by using a modification of the method of Weber and Osborne (25).

Cellular fatty acid analysis. All glutamate-fermenting strains were cultivated at $37^{\circ} \mathrm{C}$ for 1 day in peptone-yeast extract-glucose medium (14) without added Tween 80. C. estertheticum was grown at $10^{\circ} \mathrm{C}$ for 5 days. Cells from three culture tubes were collected by centrifugation, washed three times in $1 \%$ (wt/vol) $\mathrm{NaCl}$, and stored at $-20^{\circ} \mathrm{C}$ until use. Fatty acid methyl esters (FAMEs) were obtained from the biomass after saponification and methylation as described previously $(22,24)$. FAMEs were separated by gas-liquid chromatography by using a mode 5898A microbial identification system (Microbial ID, Inc., Newark, Del.). Peaks were automatically integrated, and fatty acid assignments and percentages were calculated by using the Microbial ID System Library Generation Software (22)

16S rRNA gene sequence determination and phylogenetic analysis. 16S rRNA genes of strain $\mathrm{Cm} 19^{\mathrm{T}}$ were amplified as described previously (17) and were purified by using a Prep-A-Gene kit (Bio-Rad, Hercules, Calif.) according to the manufacturer's instructions. 16S ribosomal DNA fragments were sequenced by using a Taq DyeDeoxy terminator cycle sequencing kit (Applied Biosystems, Inc. Foster City, Calif.) and a model 373A automatic DNA sequencer (Applied Biosystems, Inc.). The new sequence was compared with sequences of reference organisms in the EMBL and GenBank data libraries. Sequences were aligned by using the PILEUP program (8), and the alignments were corrected manually. Phylogenetic analyses were performed with the PHYLIP package (10). A distance matrix was calculated by using the program DNADIST, and a phylogenetic tree was constructed by the neighbor-joining method with the program NEIGHBOR.

Nucleotide sequence accession number. The EMBL accession number for the 16S rRNA gene sequence of strain $\mathrm{Cm} 19^{\mathrm{T}}$ is $\mathrm{X} 96736$.

\section{RESULTS}

Morphological, physiological, and biochemical characteristics. The new isolates $\left(\mathrm{Cm} 17, \mathrm{Cm} 19^{\mathrm{T}}, \mathrm{Cm} 20\right.$, and $\left.\mathrm{Cm} 21\right)$ were motile, straight or occasionally slightly bent rods $(0.75$ to 1.0 by 3.2 to $8 \mu \mathrm{m}$ ) with elliptical, subterminally located spores swelling the mother cells (Fig. 1). Cells from a 10-h culture stained gram negative. The analysis of the cell wall peptidoglycan of all strains revealed meso-diaminopimelic acid in the peptide side chain. Surface colonies on Columbia sheep blood agar were tiny (diameter, 1 to $2 \mathrm{~mm}$ ), round, white-grey, and opaque and did not exhibit hemolytic activity. On RCM agar the colonies were white-grey, irregular, and translucent. Growth of colonies was evaluated after $48 \mathrm{~h}$.

Strain $\mathrm{Cm} 19^{\mathrm{T}}$ grew at temperatures ranging from 10 to $43^{\circ} \mathrm{C}$ and grew optimally at temperatures between 37 and $40^{\circ} \mathrm{C}$. There was no growth at $45.5^{\circ} \mathrm{C}$. The $\mathrm{pH}$ range for growth was 5.4 to 9.0 , with a broad $\mathrm{pH}$ optimum between $\mathrm{pH} 6.4$ and 7.8 . Under optimum conditions (PY medium containing glutamate, $\mathrm{pH}$ 7) strain $\mathrm{Cm} 19^{\mathrm{T}}$ grew with doubling times of $33 \mathrm{~min}$ at $37^{\circ} \mathrm{C}$ and $18 \mathrm{~h}$ at $10^{\circ} \mathrm{C}$

The fermentation products determined for strain $\mathrm{Cm} 19^{\mathrm{T}}$ after growth in PY medium were acetate (16 to $20 \mathrm{mM})$, butyrate ( 7 to $9 \mathrm{mM}$ ), ethanol ( 3 to $4 \mathrm{mM}$ ), hydrogen, and carbon dioxide. All four strains grew with glutamate and histidine but not with glutamine. None of the nine sugars tested except ribose was utilized; ribose was weakly utilized by strain $\mathrm{Cm} 19^{\mathrm{T}}$. Ethanolamine was partially degraded by three strains,
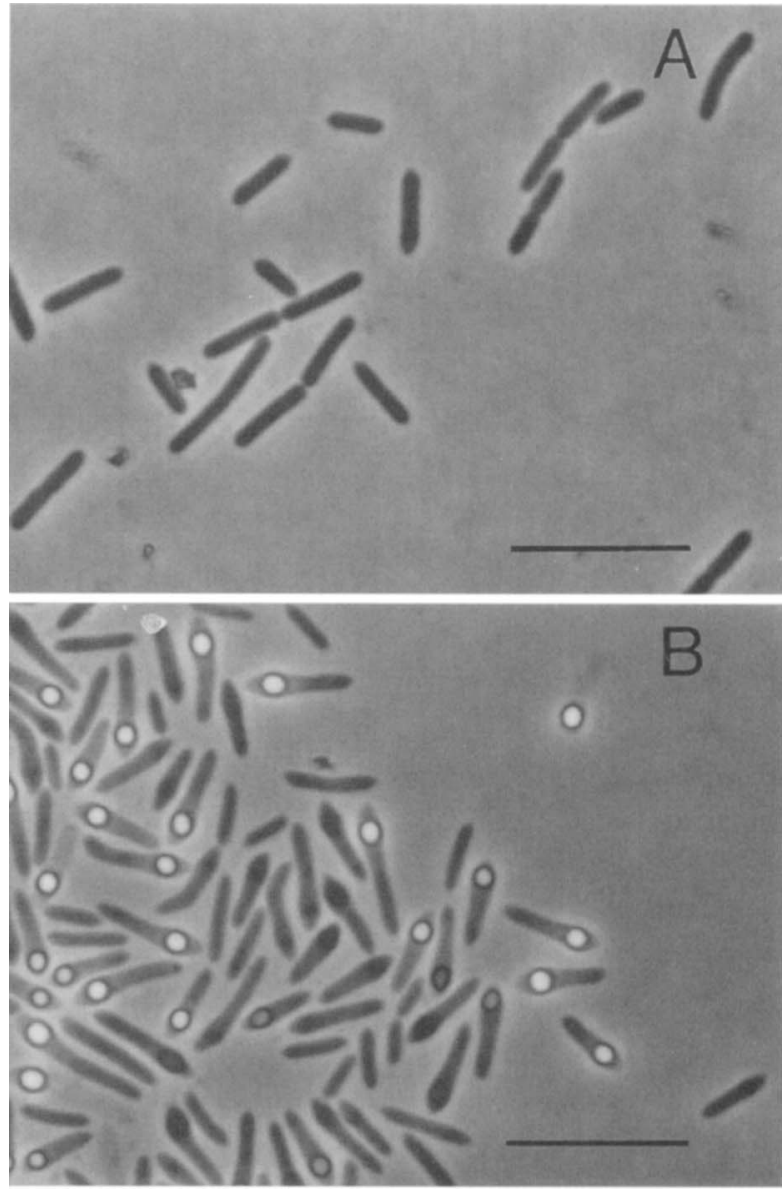

FIG. 1. Phase-contrast micrographs of vegetative cells (A) and sporulated cells (B) of strain $\mathrm{Cm} 19^{\mathrm{T}}$ grown in PY medium and on RCM agar, respectively. Bar $=10 \mu \mathrm{m}$

including strain $\mathrm{Cm} 19^{\mathrm{T}}$. All of the strains produced indole, but none hydrolyzed gelatin or showed lipolytic activity or a positive lecithinase reaction on egg yolk agar plates. The results of the various tests performed in the comparison with other glutamate-fermenting clostridia are summarized in Table 1 . Of the 29 enzymatic reactions tested with the API ATB-32A Identification System for Anaerobes, only indole production was positive for the four strains.

All of the strains were sensitive to tetracycline, chloramphenicol, rifampin, and neomycin. Strain $\mathrm{Cm} 19^{\mathrm{T}}$ was also sensitive to penicillin $G$, ampicillin, and erythromycin. Strains $\mathrm{Cm} 19^{\mathrm{T}}, \mathrm{Cm} 20$, and $\mathrm{Cm} 21$ were resistant to clindamycin, but strain $\mathrm{Cm} 17$ was sensitive.

$G+C$ content and DNA-DNA homology. The DNA base composition of strain $\mathrm{Cm} 19^{\mathrm{T}}$ was $27 \mathrm{~mol} \% \mathrm{G}+\mathrm{C}$. The level of DNA-DNA relatedness between strain $\mathrm{Cm} 19^{\mathrm{T}}$ and C. malenominatum DSM $1127^{\mathrm{T}}$ was $54 \%$, and the level of DNA-DNA relatedness between strain $\mathrm{Cm} 19^{\mathrm{T}}$ and $C$. cochlearium DSM 667 was $46 \%$.

Protein gel electrophoretic patterns. The protein patterns of $\mathrm{Cm} 17, \mathrm{Cm} 19^{\mathrm{T}}, \mathrm{Cm} 20$, and $\mathrm{Cm} 21$ were compared to those of $C$. malenominatum, $C$. cochlearium, $C$. tetanomorphum, C. tetani, C. subterminale, C. sporosphaeroides, C. putrificum, C. limosum, $C$. symbiosum, and C. histolyticum. Figure 2 shows the similarities among strains $\mathrm{Cm} 17, \mathrm{Cm} 19^{\mathrm{T}}, \mathrm{Cm} 20$, and $\mathrm{Cm} 21$ and the differences from strains of $C$. malenominatum and $C$. subter- 
TABLE 1. Biochemical properties of the newly isolated strains and strains of other glutamate-fermenting clostridia

\begin{tabular}{|c|c|c|c|c|c|c|c|c|c|c|c|c|c|c|c|c|c|}
\hline \multirow{2}{*}{ Strain } & \multicolumn{2}{|c|}{ Degradation of: } & \multicolumn{2}{|c|}{ Production of: } & \multirow{2}{*}{$\begin{array}{c}\text { Gelatin } \\
\text { hydro- } \\
\text { lysis }\end{array}$} & \multicolumn{3}{|c|}{ Fermentation of: } & \multicolumn{9}{|c|}{ Degradation of sugars } \\
\hline & $\begin{array}{l}\text { Ethanol- } \\
\text { amine }\end{array}$ & Choline & Indole & Lipase & & Glutamate & Glutamine & Histidine & Glucose & Fructose & Ribose & Xylose & Maltose & Cellobiose & Inositol & Sorbitol & Salicin \\
\hline $\mathrm{Cm} 17$ & $-^{a}$ & - & + & - & - & + & - & + & - & - & - & - & - & - & - & - & - \\
\hline $\mathrm{Cm} 19^{\mathrm{T}}$ & $(+)$ & - & + & - & - & + & - & + & - & - & $(+)$ & - & - & - & - & - & - \\
\hline $\mathrm{Cm} 20$ & $(+)$ & - & + & - & - & + & - & + & - & - & - & - & - & - & - & - & - \\
\hline $\mathrm{Cm} 21$ & $(+)$ & - & + & - & - & + & - & $(+)$ & - & - & - & - & - & - & - & - & - \\
\hline C. malenominatum DSM $1127^{\mathrm{T}}$ & - & - & + & - & - & + & - & $(+)$ & - & - & - & - & - & - & - & - & - \\
\hline \multicolumn{18}{|l|}{ C. cochlearium } \\
\hline DSM 666 & - & - & + & - & _- & + & - & + & - & - & - & - & - & - & - & - & - \\
\hline DSM 667 & - & - & + & - & - & + & - & + & - & - & - & - & - & - & - & - & - \\
\hline DSM 2153 & - & - & + & - & + & + & - & + & - & - & - & - & - & - & - & - & - \\
\hline DSM 3588 & - & - & - & - & + & + & - & + & - & - & - & - & - & - & - & - & - \\
\hline DSM $1285^{\mathrm{T}}$ & - & - & - & - & + & + & - & + & - & - & - & - & - & - & - & - & - \\
\hline \multicolumn{18}{|l|}{ C. tetanomorphum } \\
\hline DSM 528 & + & - & $(+)$ & + & - & + & & & + & $(+)$ & + & + & + & - & - & - & - \\
\hline DSM 665 & + & - & + & + & - & + & & & + & $(+)$ & + & + & + & - & + & + & $(+)$ \\
\hline DSM $4474^{\mathrm{T}}$ & + & - & + & + & - & + & - & + & + & + & + & + & + & - & + & + & $(+)$ \\
\hline NCTC 500 & + & - & + & + & - & + & & & + & - & + & + & + & $(+)$ & + & + & $(+)$ \\
\hline MG1 & + & - & + & + & - & + & & & + & + & + & + & + & $(+)$ & + & + & - \\
\hline S2;T4/1 & + & - & + & + & - & + & & & + & - & + & + & + & - & + & + & - \\
\hline $10 ; \mathrm{T} 10 / 3$ & + & - & + & + & - & + & & & + & - & + & + & + & - & + & - & + \\
\hline $\mathrm{L} 97$ & + & - & + & + & - & + & & & + & - & + & + & + & - & + & - & $(+)$ \\
\hline E4539 & + & - & + & + & - & + & & & + & - & + & + & + & + & + & - & - \\
\hline \multicolumn{18}{|l|}{ C. tetani } \\
\hline 34946A & + & $(+)$ & + & + & + & + & & & - & - & - & - & - & - & - & - & - \\
\hline $\mathrm{E} 4222$ & + & $(+)$ & $(+)$ & + & + & + & & & - & - & - & - & - & - & + & - & - \\
\hline C. limosum DSM $1400^{\mathrm{T}}$ & + & + & - & - & + & $t^{b}$ & & & - & - & - & - & - & - & - & - & - \\
\hline C. sporosphaeroides DSM $1294^{\mathrm{T}}$ & - & - & $--^{b}$ & $-{ }^{b}$ & $-b$ & $t^{b}$ & & & + & + & + & - & - & + & - & - & - \\
\hline C. subterminale DSM 2636 & ND & ND & $-{ }^{b}$ & $--^{b}$ & $t^{b}$ & $+^{b}$ & & & - & - & - & - & - & - & - & - & - \\
\hline
\end{tabular}

${ }^{a}-$, negative; +, positive; (+), weakly positive or (in case of sugar fermentation) an increase in optical density of 0.49 to 0.89 unit or a decrease in culture $\mathrm{pH}$ of 0.3 to $0.6 \mathrm{pH}$ unit; $\mathrm{ND}$, not determined. ${ }^{b}$ Data from reference $1,2,3,9$, or 12 . 


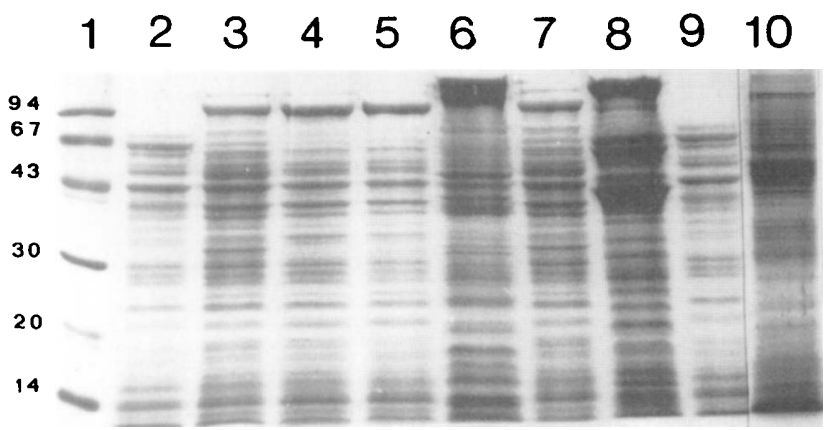

FIG. 2. Polyacrylamide gel electrophoretic protein patterns of the new soil isolates and strains of $C$. malenominatum and $C$. subterminale. Lane 1, protein standard mixture; lane 2, Cm17; lane $3, \mathrm{Cm} 19^{\mathrm{T}}$; lane $4, \mathrm{Cm} 20$; lane 5, Cm21; lane 6, C. malenominatum DSM $1127^{\mathrm{T}}$; lane $7, \mathrm{Cm} 19^{\mathrm{T}}$; lane 8, C. subterminale DSM 2636; lane 9, Cm17; lane 10, C. subterminale DSM $6970^{\mathrm{T}}$. The values on the left indicate the positions of protein standards (in kilodaltons).

minale. The protein patterns of $\mathrm{Cm} 20$ and $\mathrm{Cm} 21$ were identical, while $\mathrm{Cm} 19^{\mathrm{T}}$ also produced one typical band above the $30-\mathrm{kDa}$ marker protein. The protein pattern of $\mathrm{Cm} 17$ differed from the patterns of the other soil isolates by lacking the prominent band near the $94-\mathrm{kDa}$ protein. The differences between the protein patterns of the soil isolates and the patterns of strains of $C$. cochlearium, C. tetanomorphum, and C. tetani are shown in Fig. 3.

Furthermore, there was no similarity between the protein patterns of the four soil isolates and the patterns of $C$. limosum, C. symbiosum, C. putrificum, and C. histolyticum (data not shown). The protein pattern of $C$. sporosphaeroides showed some similarity to the patterns of strains $\mathrm{Cm} 19^{\mathrm{T}}$ and $\mathrm{Cm} 20$. However, $C$. sporosphaeroides, in contrast to the four new strains, is saccharolytic (it degrades several sugars, including glucose, fructose, ribose, and cellobiose) and is unable to produce indole.

Cellular fatty acid composition. New isolates $\mathrm{Cm} 17, \mathrm{Cm} 19^{\mathrm{T}}$, $\mathrm{Cm} 20, \mathrm{Cm} 21$ had very similar fatty acid patterns which differed significantly from those of the other glutamate-fermenting species analyzed in parallel (Table 2). The four new strains contained predominantly even-numbered, saturated $C_{14}$ to $C_{18}$ fatty acids (mean, $45 \%$ of the total fatty acids), monounsaturated $\mathrm{C}_{16}$ and $\mathrm{C}_{18}$ fatty acids (mean, $36.3 \%$ of the total fatty acids), and $\mathrm{C}_{14}$ and $\mathrm{C}_{16}$ aldehydes and dimethylacetals (mean, $14.4 \%$ of the total fatty acids). Odd-numbered fatty acids were present in only small amounts $\left(1 \% \mathrm{C}_{15}\right.$ fatty acid), and iso- and anteiso-branched fatty acids, as well as cyclopropane fatty acids, were not detected in these strains.

The patterns of the soil strains were different from the pattern of $C$. estertheticum, which contained cyclopropane fatty acids $\left(4.3 \% \mathrm{C}_{17: 0}\right.$ cyclo and $3.4 \% \mathrm{C}_{17: 0}$ cyclo dimethylacetal) and from the pattern of $C$. subterminale, which contained about $20 \%$ iso- and anteiso-branched fatty acids. C. tetanomorphum was readily distinguished from the new isolates because it produced $\mathrm{C}_{17: 0}$ cyclopropane fatty acids, as well as aldehydes and dimethylacetals. Other glutamate-fermenting species, such as C. cochlearium, C. malenominatum, $C$. tetani, and C. limosum, were similar to the soil isolates in lacking iso- and anteisobranched fatty acids, cyclopropane fatty acids, and odd-numbered fatty acids (except for small amounts in C. tetani and $C$. limosum). These species, however, differed from the soil strains in their overall quantitative fatty acid compositions. When principal-component analysis was used, each species formed a well-separated cluster (data not shown).
16S rRNA gene sequence determination. The 16S rRNA sequence of strain $\mathrm{Cm} 19^{\mathrm{T}}$ was determined by direct sequencing of PCR-amplified ribosomal DNA products. Sequence similarity calculations performed with sequences of reference organisms obtained from EMBL and GenBank data libraries revealed that strain $\mathrm{Cm} 19^{\mathrm{T}}$ belonged to the Clostridium subphylum of the gram-positive bacteria and was a member of Clostridium cluster I of Collins et al. (4). A phylogenetic tree showing the position of strain $\mathrm{Cm} 19^{\mathrm{T}}$ within Clostridium cluster I is depicted in Fig. 4. This tree demonstrates that the soil bacterium represents a new subline quite distinct from other glutamate-fermenting clostridia (viz., $C$. malenominatum, $C$. cochlearium, C. tetanomorphum, and C. tetani).

\section{DISCUSSION}

The genus Clostridium is one of the largest genera of bacteria, consisting of more than 100 species, and as presently defined is phenotypically very heterogeneous. Currently, all gram-positive rods which are obligately anaerobic, form endospores, and are unable to carry out dissimilatory sulfate reduction are assigned to this genus. In addition to the marked phenotypic heterogeneity of the clostridia, this genus has also been shown to exhibit remarkable phylogenetic diversity (4). As a result of phylogenetic studies, taxonomic reorganization of the genus has commenced, and several species have recently been assigned to other genera (4).

Physiological and biochemical activities, as well as spore characteristics, are the main characteristics for identifying clostridial species by phenotypic criteria given in Bergey's.Manual of Systematic Bacteriology (3). According to the traditional phenotypic characteristics (no acid is produced from glucose, gelatin is not hydrolyzed, indole is produced) and the identification key for clostridia, strains $\mathrm{Cm} 17, \mathrm{Cm} 19^{\mathrm{T}}, \mathrm{Cm} 20$, and $\mathrm{Cm} 21$ could be misidentified as $C$. malenominatum.

A 16S rRNA analysis, however, showed that, although the soil isolates and $C$. malenominatum are members of Clostridium cluster I, they are nevertheless phylogenetically separate (exhibiting approximately 6\% sequence divergence). Similarly, strain $\mathrm{Cm} 19^{\mathrm{T}}$ was found to be genealogically distinct from other classical glutamate-fermenting clostridia, including $C$. limosum, $C$. sporosphaeroides, $C$. symbiosum, $C$. tetanomorphum, $C$. cochlearium, and $C$. tetani, and the last three species display a closer affinity with $C$. malenominatum. As determined by tree topology considerations, the nearest relatives of the new soil bacterium are $C$. estertheticum, Clostridium argentinense, and $C$. subterminale (Fig. 4). Sequence divergence

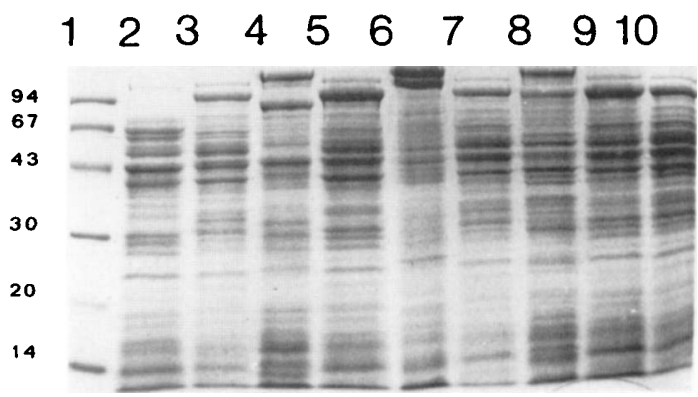

FIG. 3. Polyacrylamide gel electrophoretic protein patterns of the soil isolates and strains of $C$. cochlearium, C. tetanomorphum, and C. tetani. Lane 1 , protein standard mixture; lane $2, \mathrm{Cm} 17$; lane $3, \mathrm{Cm} 19^{\mathrm{T}}$; lane $4, C$. cochlearium DSM 1285 ${ }^{\mathrm{T}}$; lane 5, Cm20; lane 6, C. tetanomorphum DSM 4474 ${ }^{\mathrm{T}}$; lane 7 $\mathrm{Cm} 19^{\mathrm{T}}$; lane 8, C. tetani E4222; lane 9, Cm21; lane 10, Cm19 ${ }^{\mathrm{T}}$. The values on the left indicate the positions of protein standards (in kilodaltons). 
TABLE 2. Cellular fatty acid compositions of strains $\mathrm{Cm} 17, \mathrm{Cm} 19^{\mathrm{T}}, \mathrm{Cm} 20$, and $\mathrm{Cm} 21$ and some other glutamate-fermenting clostridia

\begin{tabular}{|c|c|c|c|c|c|c|c|c|c|c|c|c|}
\hline \multirow{2}{*}{$\begin{array}{l}\text { Equivalent } \\
\text { chain } \\
\text { length }\end{array}$} & \multirow[b]{2}{*}{ FAME $^{a}$} & \multicolumn{11}{|c|}{$\%$ in: } \\
\hline & & $\begin{array}{l}\text { Strain } \\
\mathrm{Cm} 17\end{array}$ & $\begin{array}{l}\text { Strain } \\
\mathrm{Cm} 19^{\mathrm{T}}\end{array}$ & $\begin{array}{l}\text { Strain } \\
\mathrm{Cm} 20\end{array}$ & $\begin{array}{l}\text { Strain } \\
\mathrm{Cm} 21\end{array}$ & $\begin{array}{l}\text { C. estertheticum } \\
\text { DSM } 8809^{\mathrm{T}}\end{array}$ & $\begin{array}{c}\text { C. subterminale DSM } 6970^{\mathrm{T}} \text {, } \\
\text { DSM } 2636, \text { and } \\
\text { DSM } 758^{b}\end{array}$ & $\begin{array}{l}\text { C. cochlearium DSM } 666, \\
\text { DSM } 667, \text { DSM } 1285^{\mathrm{T}}, \\
\text { DSM } 2153 \text {, and DSM } 3588^{b}\end{array}$ & $\begin{array}{l}\text { C. tetani } \mathrm{E} 4222 \\
\text { and } 34946 \mathrm{~A}^{b}\end{array}$ & $\begin{array}{l}\text { C. tetanomorphum DSM } 528, \\
\text { DSM } 665 \text {, DSM } 4474^{\mathrm{T}} \text {, } \\
\text { NCTC } 500 \text {, and } \mathrm{MG}^{b}\end{array}$ & $\begin{array}{l}\text { C. malenominatum } \\
\text { DSM } 1127^{\mathrm{T}}\end{array}$ & $\begin{array}{l}\text { C. limosum } \\
\text { DSM } 1400^{\mathrm{T}}\end{array}$ \\
\hline 12.000 & 12:0 & & & & & & 1.0 & 1.9 & 1.6 & & & 1.7 \\
\hline 12.474 & $11: 0 \mathrm{dma}$ & & & & & & & & 0.9 & & & \\
\hline 12.614 & iso $13: 0$ & & & & & & 2.3 & & & & & \\
\hline 12.766 & Unknown & & & & & & & & 1.1 & & & \\
\hline 12.925 & $14: 0$ ald & & & & & & 1.0 & 0.8 & 2.0 & 2.1 & & 1.0 \\
\hline 13.766 & Unknown & & & & & & & 1.6 & 1.4 & & & 0.9 \\
\hline 13.811 & Unknown & 2.3 & 1.1 & 1.6 & 1.3 & & & 4.2 & 1.3 & & 4.3 & 2.6 \\
\hline $14: 000$ & 14:0 & 34.0 $0^{c}$ & 32.2 & 34.5 & 32.2 & 28.4 & 7.3 & 29.2 & 34.1 & 23.5 & 23.3 & 24.0 \\
\hline 14.293 & 14:1 $c 7 \mathrm{dma}$ & & & & & & & 1.5 & 3.2 & 1.2 & & 1.1 \\
\hline 14.478 & $14: 0 \mathrm{dma}$ & 1.0 & 1.3 & 1.4 & 1.5 & & 3.0 & 3.5 & 7.8 & 7.2 & & 4.2 \\
\hline 14.622 & iso $15: 0$ & & & & & & 6.8 & & & & & \\
\hline 14.712 & anteis. 15:0 & & & & & & 4.0 & & & & & \\
\hline $14.757-78$ & Unknown & 2.7 & 2.5 & 4.0 & 2.5 & 8.0 & & 2.2 & 2.7 & 2.5 & 1.2 & 2.9 \\
\hline 14.946 & $16: 0$ ald & & & & & & 2.3 & & & 1.0 & & \\
\hline 15:000 & 15:0 & 0.7 & 1.0 & 1.0 & 1.0 & & & & 0.9 & & & 2.5 \\
\hline 15.117 & iso $15: 0 \mathrm{dma}$ & & & & & & 2.0 & & & & & \\
\hline 15.772 & $16: 1 c 7$ & 14.3 & 11.2 & 11.9 & 11.6 & 3.6 & 3.1 & 8.5 & 4.8 & 3.6 & 13.2 & 7.9 \\
\hline 15.815 & $16: 1 c^{9}$ & 21.8 & 18.2 & 19.3 & 18.9 & 11.5 & 5.3 & 15.8 & 7.9 & 2.1 & 39.1 & 9.7 \\
\hline 15.905 & $16: 1 c 11$ & 2.3 & 2.4 & 1.9 & 2.3 & 7.0 & & 1.2 & & 1.0 & 2.1 & 2.3 \\
\hline 16.000 & $16: 0$ & 9.0 & 13.0 & 10.7 & 11.8 & 8.6 & 27.8 & 17.8 & 16.3 & 35.5 & 13.8 & 26.5 \\
\hline 16.243 & 16:1 $17 \mathrm{dma}$ & 2.3 & 3.4 & 3.1 & 3.3 & 1.4 & 2.1 & 2.7 & 4.1 & 5.3 & & 3.4 \\
\hline 16.288 & 16:1 $c 9 \mathrm{dma}$ & 7.5 & 9.7 & 8.1 & 9.3 & 22.1 & 2.5 & 6.2 & 7.5 & 4.5 & 3.1 & 7.0 \\
\hline 16.383 & Unknown & & & & & & & & & 1.0 & & \\
\hline 16.476 & $16: 0 \mathrm{dma}$ & 0.8 & 1.8 & 1.5 & 1.6 & & 9.4 & 2.9 & 2.8 & 4.2 & & 1.9 \\
\hline 16.629 & iso $17: 0$ & & & & & & 5.8 & & & & & \\
\hline $\begin{array}{l}16.884 \\
17108\end{array}$ & 17:0 cyc & & & & & 4.3 & 1.2 & & & 2.4 & & \\
\hline $\begin{array}{l}17.108 \\
17.359\end{array}$ & $\begin{array}{l}\text { Unknown } \\
\text { 17:0 cyc dma }\end{array}$ & & & & & 3.4 & & & & 3.6 & & \\
\hline $17.763-70$ & $18: 1 c 9$ & 1.2 & 1.1 & 1.0 & 1.0 & & 1.3 & 1.4 & 1.0 & & 1.6 & 1.0 \\
\hline 17.820 & 18:1 $c 11$ & & & & & & 1.5 & 1.3 & & & & 1.0 \\
\hline 18.000 & 18:0 & 1.0 & 0.7 & & 0.8 & & 5.3 & 0.9 & 0.9 & & 1.1 & 1.0 \\
\hline
\end{tabular}

${ }^{a}$ Fatty acids that occur in all strains in small amounts $(<1 \%)$ are not listed. Abbreviations: dma, dimethylacetal; ald, aldehyde; cyc, cyclopropane; $c$, cis.

${ }^{b}$ Values are arithmetic means.

${ }^{c}$ The values in boldface type are the values for major fatty acids. 


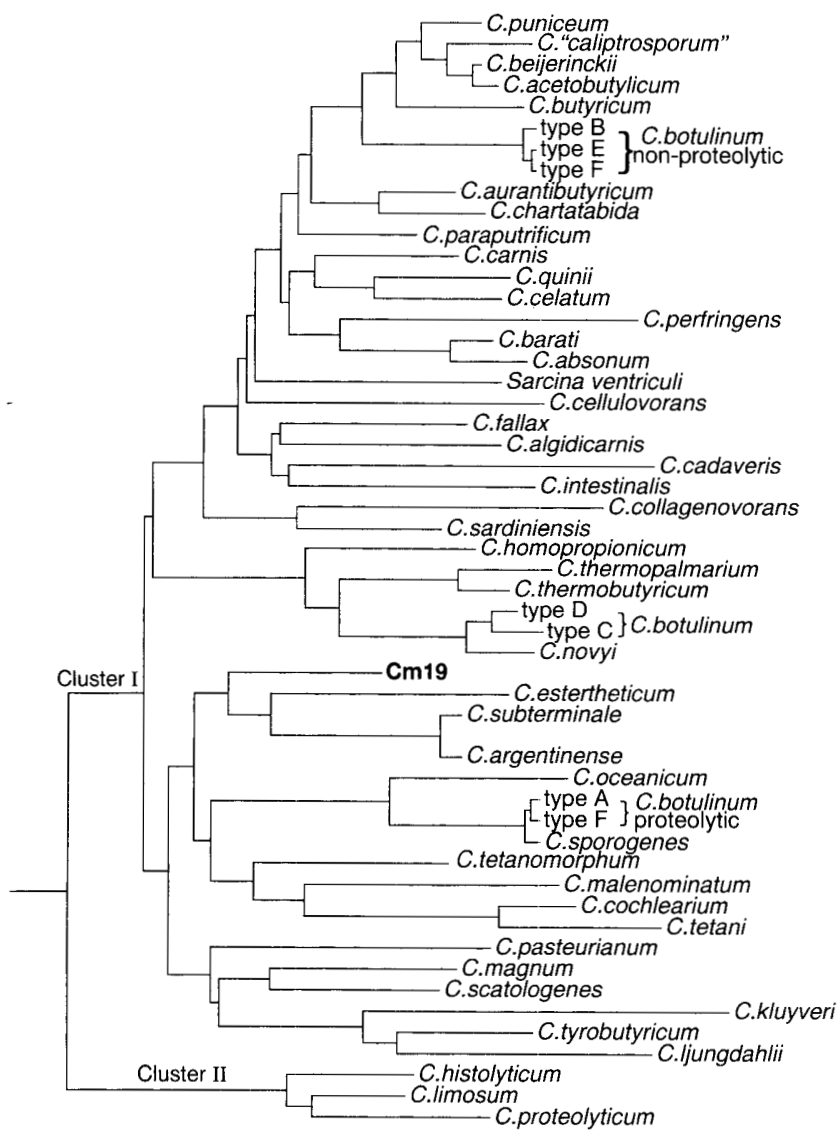

FIG. 4. Dendrogram showing the phylogenetic position of strain $\mathrm{Cm} 19^{\mathrm{T}}$ within the Clostridium cluster I (genus Clostridium sensu stricto). The tree was constructed by using the neighbor-joining method.

values of approximately $95 \%$, however, show that this association is not very close.

C. estertheticum, which was isolated from spoiled vacuumpacked refrigerated beef, is a butanol-producing, saccharolytic species which is psychrophilic and has a maximum growth temperature of less than $20^{\circ} \mathrm{C}(5,6)$. Unlike C. estertheticum, the four soil strains are mesophilic, do not ferment sugars (except for weak ribose fermentation by strain $\mathrm{Cm} 19^{\mathrm{T}}$ ), do not produce butanol as a fermentation product, and have a different cellular fatty acid pattern. $C$. estertheticum and $C$. tetanomorphum, both of which are butanol-producing clostridia, contain cyclopropane fatty acids which are not present in the four soil strains.

The new strains also differed from $C$. subterminale in cellular fatty acid composition, soluble protein pattern, and enzymatic reactions in API ATB-32A tests. Unlike C. subterminale and the phylogenetically closely related organism $C$. argentinense, strains $\mathrm{Cm} 17, \mathrm{Cm} 19^{\mathrm{T}}, \mathrm{Cm} 20$, and $\mathrm{Cm} 21$ did not hydrolyze gelatin, digest milk, produce isobutyric and isovaleric acids as fermentation products, or contain iso- and anteiso-branched fatty acids. In addition, strains $\mathrm{Cm} 17, \mathrm{Cm} 19^{\mathrm{T}}, \mathrm{Cm} 20$, and $\mathrm{Cm} 21$ were indole positive.

Although the new soil bacterium phenotypically resembled C. malenominatum, it could be distinguished by its cell size (cells of $C$. malenominatum are 0.3 to $0.6 \mu \mathrm{m}$ in diameter, which is about half the diameter of cells of strains $\mathrm{Cm} 17$, $\mathrm{Cm} 19^{\mathrm{T}}, \mathrm{Cm} 20$, and $\mathrm{Cm} 21$ ), its different cellular protein patterns, and its different cellular fatty acid composition $(3.1 \%$
$\mathrm{C}_{16: 1}$ cis 9 aldehydes and dimethylacetal in $C$. malenominatum versus 11.6 to $16.2 \%$ aldehydes and dimethylacetals in strains $\mathrm{Cm} 17, \mathrm{Cm} 19^{\mathrm{T}}, \mathrm{Cm} 20$, and $\mathrm{Cm} 21$ ).

No difference in the cell wall peptidoglycans of strains $\mathrm{Cm} 17, \mathrm{Cm} 19^{\mathrm{T}}, \mathrm{Cm} 20$, and $\mathrm{Cm} 21$ and $C$. malenominatum was observed. The four soil isolates and $C$. malenominatum DSM $1127^{\mathrm{T}}$ were analyzed in parallel and contained meso-diaminopimelic acid in their peptidoglycans, which is the dominant murine type in clostridia. Therefore, previous reports $(3,11)$ on the presence of an L-lysine-aspartate peptidoglycan type in C. malenominatum need to be corrected.

The results of morphological, physiological, and biochemical studies, including comparative analyses of $16 \mathrm{~S}$ rRNA sequences, cell protein patterns, and cellular fatty acids, clearly demonstrate that strains $\mathrm{Cm} 17, \mathrm{Cm} 19^{\mathrm{T}}, \mathrm{Cm} 20$, and $\mathrm{Cm} 21$ belong to a new species of the genus Clostridium, for which we propose the name Clostridium pascui.

Description of Clostridium pascui sp. nov. Clostridium pascui (pas'cu.i L. gen. n. pascui, of a pasture [soil], referring to the habitat where the organism was isolated). Cells are rod shaped ( 0.75 to 1.0 by 3.2 to $8 \mu \mathrm{m})$, occur singly or in pairs, and are motile. Spores are elliptical and subterminal and swell the cells. Cells stain gram negative. Colonies on sheep blood agar are up to $2 \mathrm{~mm}$ in diameter, round, white-grey, opaque, and nonhemolytic. The cell wall peptidoglycan contains meso-diaminopimelic acid as the dibasic amino acid.

The temperature range of growth is 10 to $43^{\circ} \mathrm{C}$, and the optimum temperature is 37 to $40^{\circ} \mathrm{C}$. The $\mathrm{pH}$ range is 5.5 to 9.0 , and the broad optimum $\mathrm{pH}$ is $\mathrm{pH} 6.4$ to 7.8 .

Carbohydrates are not fermented (except for a weak reaction by one strain), nitrate and sulfate are not reduced, lipase and lecithinase are not produced, and gelatin is not hydrolyzed. Indole is produced. Glutamate and histidine are fermented. Acid and gas are produced. The fermentation products formed are acetate, butyrate, ethanol, $\mathrm{H}_{2}$, and $\mathrm{CO}_{2}$. The major cellular fatty acids are $\mathrm{C}_{14: 0}, \mathrm{C}_{16: 0}, \mathrm{C}_{16: 1}$ cis 7 , and $\mathrm{C}_{16: 1}$ cis 9 acids and aldehydes.

The $\mathrm{G}+\mathrm{C}$ content of the DNA of strain $\mathrm{Cm} 19^{\mathrm{T}}$ is $27 \mathrm{~mol} \%$.

Isolated from a donkey pasture in Pakistan. The true habitat is unknown and may be the intestinal tract of donkeys.

The type strain is strain $\mathrm{Cm} 19$, which has been deposited in the Deutsche Sammlung von Mikroorganismen und Zellkulturen GmbH, Braunschweig, Germany, as strain DSM 10365.

\section{ACKNOWLEDGMENTS}

We thank G. Pötter, B. Frerichs, and B. Merkhoffer (Deutsche Sammlung von Mikroorganismen und Zellkulturen $\mathrm{GmbH}$, Braunschweig, Germany) for skillful assistance and help in the fatty acid analysis, N. Weiss (Deutsche Sammlung von Mikroorganismen und Zellkulturen $\mathrm{GmbH}$ ) for performing the peptidoglycan analyses, and G. Schallehn (University of Bonn, Bonn, Germany) for performing the toxigenicity tests. We are grateful to $\mathrm{G}$. Gottschalk (Institut für Mikrobiologie der Universität Göttingen, Göttingen, Germany) for fruitful discussions and continuous support.

\section{REFERENCES}

1. Buckel, W. 1980. Analysis of the fermentation pathways of clostridia using double labelled glutamate. Arch. Microbiol. 127:167-169.

2. Buckel, W., and H. A. Barker. 1974. Two pathways of glutamate fermentation by anaerobic bacteria. J. Bacteriol. 117:1248-1260.

3. Cato, E. P., W. L. George, and S. M. Finegold. 1986. Genus Clostridium Prazmowski 1880, $23^{\text {AL }}$, p. 1141-1200. In P. H. A. Sneath, N. S. Mair, M. E. Sharpe, and J. G. Holt (ed.), Bergey's manual of systematic bacteriology, vol. 2. The Williams \& Wilkins Co., Baltimore, Md.

4. Collins, M. D., P. A. Lawson, A. Willems, J. J. Cordoba, J. FernandezGarayzabal, P. Garcia, J. Cai, H. Hippe, and J. A. E. Farrow. 1994. The phylogeny of the genus Clostridium: proposal of five new genera and eleven new species combinations. Int. J. Syst. Bacteriol. 44:812-826.

5. Collins, M. D., U. M. Rodrigues, R. H. Dainty, R. A. Edwards, and T. A. 
Roberts. 1992. Taxonomic studies on a psychrophilic Clostridium from vacuum-packed beef: description of Clostridium estertheticum sp. nov. FEMS Microbiol. Lett. 96:235-240.

6. Dainty, R. H., R. A. Edwards, and C. M. Hibbard. 1989. Spoilage of vacuumpacked beef by a Clostridium sp. J. Sci. Food Agric. 49:473-486.

7. DeLey, J., H. Cattoir, and R. Reynaerts. 1970. The quantitative measurement of DNA hybridization from renaturation rates. Eur. J. Biochem. 12: $133-142$.

8. Devereux, J., P. Haeberli, and D. Smithies. 1984. A comprehensive set of sequence analysis programs for the VAX. Nucleic Acids Res. 12:387-395.

9. Elsden, S. R., and M. G. Hilton. 1979. Amino acid utilisation patterns in clostridial taxonomy. Arch. Microbiol. 123:137-141.

10. Felsenstein, J. 1989. PHYLIP - phylogeny inference package (version 3.2). Cladistics 5:164-166.

11. Gottschalk, G., J. R. Andreesen, and H. Hippe. 1981. The genus Clostridium, p. 1767-1803. In M. P. Starr, H. Stolp, H. G. Trüper, A. Balows, and H. G. Schlegel (ed.), The procaryotes. Springer-Verlag, Berlin, Germany.

12. Gottwald, M., H. Hippe, and G. Gottschalk. 1984. Formation of $n$-butanol from D-glucose by strains of the "Clostridium tetanomorphum" group. Appl. Environ. Microbiol. 48:573-576.

13. Hippe, H., J. R. Andreesen, and G. Gottschalk. 1992. The genus Clostridium-nonmedical, p. 1800-1866. In A. Balows, H. G. Trüper, M. Dworkin, W. Harder, and K.-H. Schleifer (ed.), The procaryotes, 2nd ed., vol. II. Springer-Verlag, New York, N.Y.

14. Holdeman, L. V., E. P. Cato, and W. E. C. Moore (ed.). 1977. Anaerobe laboratory manual, 4th ed. Virginia Polytechnic Institute and State University, Blacksburg.

15. Hungate, R. E. 1950. The anaerobic mesophilic cellulolytic bacteria. Bacteriol. Rev. 14:1-49.

16. Huss, V. A. R., H. Festl, and K. H. Schleifer. 1983. Studies on the spectro- photometric determination of DNA hybridization from renaturation rates. Syst. Appl. Microbiol. 4:184-192.

17. Hutson, R. A., D. E. Thompson, and M. D. Collins. 1993. Genetic interrelationships of saccharolytic Clostridium botulinum types B,E and F and related clostridia as revealed by small subunit rRNA sequences. FEMS Microbiol. Lett. 108:103-110.

18. Laemmli, U. K. 1970. Cleavage of structural proteins during the assembly of the head of bacteriophage T4. Nature (London) 227:680-685.

19. Mandel, M., and J. Marmur. 1968. Use of ultraviolet absorbance-temperature profile for determining the guanine plus cytosine content of DNA. Methods Enzymol. 12:195-206.

20. Marmur, J. 1961. A procedure for the isolation of DNA from microorganisms. J. Mol. Biol. 3:208-218.

21. Marmur, J., and P. Doty. 1962. Determination of the base composition of DNA from its thermal denaturation temperature. J. Mol. Biol. 5:109-118.

22. Meier, A., P. Kirschner, K.-H. Schröder, J. Wolters, R. M. Kroppenstedt, and E. C. Böttger. 1993. Mycobacterium intermedium sp. nov. Int. J. Syst. Bacteriol. 43:204-209.

23. Möller, B., H. Hippe, and G. Gottschalk. 1986. Degradation of various amine compounds by mesophilic clostridia. Arch. Microbiol. 145:85-90.

24. Vainshtein, M., H. Hippe, and R. M. Kroppenstedt. 1992. Cellular fatty acid composition of Desulfovibrio species and its use in classification of sulfatereducing bacteria. Syst. Appl. Microbiol. 15:554-566.

25. Weber, K., and M. Osborne. 1969. The reliability of molecular determinations by dodecyl sulfate-polyacrylamide gel electrophoresis. J. Biol. Chem. 224:4406-4412.

26. Wilde, E., H. Hippe, N. Tosunoglu, G. Schallehn, K. Herwig, and G. Gottschalk. 1989. Clostridium tetanomorphun sp. nov., nom. rev. Int. J. Syst. Bacteriol. 39:127-134. 